\title{
ПОРІВНЯЛЬНИЙ АНАЛІЗ СТРУКТУРНИХ ПОРУШЕНЬ М'ЯЗІВ ЗАДНІХ КІНЦІВОК ТА ЗМІН БІОХІМІЧНИХ ПОКАЗНИКІВ СИРОВАТКИ КРОВІ ЩУРІВ ПРИ ГОСТРІЙ ІШЕМІЇ
}

\begin{abstract}
Резюме. Гостра ішемія кінцівки виникає в результаті раптового зниження ії перфузії, що зазвичай утворюється при обтурації просвіту великих артерій унаслідок гострого тромбозу чи емболії або порушення прохідності судин, спричиненого травмами чи стисненням (включаючи накладання кровоспинних турнікетів). При відновленні кровопостачання раніше ішемізованих тканин виникає ішемічно-реперфузійний синдром (IPC), патофізіологічні ланки якого є вагомими механізмами альтерації тканин.

Мета дослідження - провести порівняльний аналіз структурних порушень м'язових волокон та змін біохімічних показників сироватки крові при гострій ішемії, спричиненій накладанням артеріального турнікета на задні кінцівки щурів.

Матеріали і методи. Проведено гістологічне та морфометричне дослідження тканин чотириголових м'язів задніх кінцівок 60 щурів за умов експериментальної гострої ішемії. У контрольній групі було 11 інтактних тварин. Гостру ішемію викликали шляхом накладання гумових джгутів SWAT (Stretch-Wrap-And-Tuck) на задні кінцівки тварин. Гістологічне дослідження проводили за загальноприйнятими методиками. Досліджували поверхневі шари чотириголового м'яза задньої кінцівки щура у середній третині стегна нижче ділянки накладання джгута. При морфометричному дослідженні визначали такі показники: пересічна площа поперечного перерізу м'язових волокон, пересічні діаметр та площа ядер м'язових волокон. Біохімічні зміни, а саме показники вмісту загального білірубіну, тригліцеридів (ТГ), холестерину, креатиніну, загального білка (ЗБ), лужної фросфратази (ЛФ) та рівень трансаміназ (АлАТ, АсАТ) визначали у сироватці крові в кожній піддослідній групі. Кількісні показники обробляли статистично.
\end{abstract}

Результати досліджень та їх обговорення. Результати аналізу отриманих даних встановили, що патологічні зміни м'язової тканини виникали вже в ранній період постішемічного ураження та наростали до кінця першої доби. При гістологічному дослідженні спостерігали наступні зміни тканин м'язів: дезорганізація структурних компонентів м'язових клітин, зменшення посмугованості, набряк, розрихленість, розволокненість та розриви м'язових волокон. Найзначнішим набряк м'язових волокон був на першу добу в третій групі щурів. Пересічна площа поперечного перерізу волокон - $(1369,15 \pm 26,57)$ мкм² $^{2}$ на $6,72 \%$ вища від показника контрольної групи ( $<<0,05)$, а пересічний діаметр - $(41,73 \pm 0,39)$ мкм на 3,37 \% перевищував контрольний по-

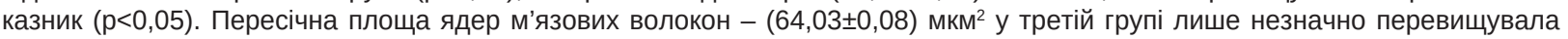

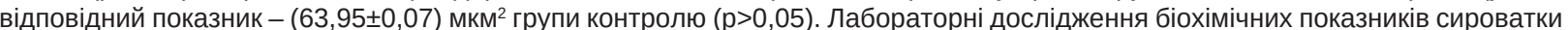
крові показали зростання активності трансаміназ, ЛФ та загального білірубіну, зниження рівня креатиніну та ЗБ у ранній реперфузійний період. Зокрема, порівняно з відповідним показником контрольної групи, рівень АлАТ досяг свого найвищого значення на першу добу (більше на 89,5 \%) (p<0,05), а показник АсАТ найвищим був у тварин з двогодинною реперфузією (більше на $78,73 \%$ ) (p<0,005), рівень ЛФ та загального білірубіну досягли свого максимуму на сьому добу (більше на 45,78 та 105,3 \% відповідно) (р<0,005). Кореляційний аналіз виявив прямий кореляційний зв'язок між показниками пересічної площі $\left(s_{s}\right)$ м'язових волокон та пересічних площ їх ядер $\left(s_{n}\right)(+0,7)$, показниками креатиніну $(+0,1)$, холестерину $(+0,4)$, загального білірубіну $(+0,1)$, АлАТ $(+0,5)$, АсАТ $(+0,5)$ та ЛФ $(+0,1)$, а також зворотний кореляційний зв'язок між показниками пересічної площі $\left(\mathrm{s}_{\mathrm{s}}\right)$ м'язових волокон і рівнем тригліцеридів $(-0,1)$ досліджуваних груп. Аналогічна закономірність виявлялась і щодо пересічної площі їх ядер $\left(\mathrm{s}_{\mathrm{n}}\right)$ та згаданих біохімічних показників.

Висновки. Результати ремоделювання м'язових волокон підтверджують розвиток у піддослідних тварин ішемічно-реперфрузійного синдрому. При дослідженні скелетної мускулатури задніх кінцівок білих щурів після гострої ішемії, спричиненої накладанням турнікета, встановлено, що ремоделювання м'язових волокон проявлялося в основному набуханням, гомогенізацією саркоплазми, порушенням лінійного розміщення ядер в міоцитах та лейкоцитарною інфьільтрацією ендо- і перимізію, міолізом із руйнуванням сарколеми та виходом ядер у міжклітинний простір. Реактивні порушення розвивались і в мікросудинах усіх сегментів та були максимально вираженими до кінця першої доби.

Ключові слова: гостра ішемія; м'язова тканина; м'язове волокно; біохімічні показники; ішемічно-реперфузійний синдром.

ВСтУП Гостра ішемія - раптове зниження перфузії кінцівки, що створює потенційну загрозу її життєздатності. Найчастішими причинами такого стану є обтурація просвіту великих артерій унаслідок гострого тромбозу чи емболії та порушення прохідності судин, спричинене їх травмами чи стисненням (включаючи накладання кровоспинних турнікетів) $[1,8]$. Частота виникнення гострої ішемії кінцівок складає 140 випадків на 1 млн населення в рік $[2,3]$. При відновленні кровопостачання раніше ішемізованих тканин виникає ішемічно-реперфузійний синдром (IPC), що характеризується порушенням клітинного обміну, накопиченням у несрізіологічних концентраціях продуктів метаболізму і розвитком ендогенної інтоксикації, які є вагомими механізмами альтерації тканин [4-11].

Багато досліджень присвячено вивченню структурних змін м'яких тканин кінцівок при розвитку IPC [12-14], проте недостатньо вивчені морфологічні порушення м'язової тканини у поєднанні зі змінами біохімічних показників крові та динаміка цих змін у різні періоди IPC.

Метою дослідження було провести порівняльний аналіз структурних порушень м'язових волокон та змін біохімічних показників при гострій ішемії, спричиненій накладанням артеріального турнікета на задні кінцівки щурів.

МАТЕРІАЛИ І МЕТОДИ Проведено гістологічне та морфометричне дослідження тканин чотириголових м'язів задніх кінцівок та визначення біохімічних показників 60 щурів за умов експериментальної гострої ішемії. У контрольній групі було 11 інтактних тварин.

Гостру ішемію викликали шляхом накладання гумових джгутів SWAT шириною 5-6 мм на задні кінцівки тварин на рівні пахової складки протягом 2 год під тіопенталонатрієвим знеболюванням. Реперфузійний синдром моделювали шляхом відновлення кровообігу в раніше ішемізованих кінцівках після зняття турнікета. Спостерігали за тваринами протягом 14 діб. 
Під час експерименту щурів поділили на 5 груп по 10 тварин у кожній. Модель раннього постішемічного періоду було представлено групами тварин із реперфузійними змінами на першу, 2-гу год та першу добу після зняття турнікета, а модель пізнього постішемічного періоду - на 7-му та 14-ту доби після зняття турнікета. Евтаназію тварин здійснювали шляхом декапітації під тіопенталонатрієвим знеболюванням.

Гістологічне дослідження проводили на кафедрі патологічної анатомії з секційним курсом та судової медицини ДВНЗ “Тернопільський державний медичний університет імені І. Я. Горбачевського МОЗ України" за загальноприйнятими методиками [15]. Досліджували поверхневі шари чотириголового м'яза задньої кінцівки щура у середній третині стегна нижче ділянки накладання джгута. 3 парафінових блоків тканини готували серії зрізів товщиною 4-5 мкм, виготовлені на мікротомі МС-2. Гістологічні зрізи забарвлювали гематоксиліном та еозином. Вивчали препарати за допомогою мікроскопа Bresser.

При морфометричному дослідженні визначали такі показники: пересічні діаметр і площу поперечного перерізу м'язових волокон та пересічну площа їх ядер. Дані параметри обраховували за допомогою програмного забезпечення для обробки й аналізу зображень SEO Image Lab срірми "Sumy Electron Optics".

Кров для дослідження отримували із верхівки серця піддослідних щурів шляхом кардіотомії перед декапітацією. Сироватку виділяли шляхом центрифугування крові протягом 15 хв при 3000 об./хв, після чого охолоджували. Біохімічні зміни, а саме показники вмісту загального білірубіну, тригліцеридів (ТГ), холестерину, креатиніну, загального білка (ЗБ), лужної фросфратази (ЛФ) та рівень трансаміназ (АлАТ, АсАТ) визначали у кожній піддослідній групі. Досліджували дані показники в міжкафредральній науково-клінічній лабораторії ДВНЗ “Тернопільський державний медичний університет імені І. Я. Горбачевського МОЗ України" реактивами ТОВ НВП "Філісіт-Діагностика", м. Дніпро.

Статистичну обробку матеріалу проводили з використанням пакета програм "Microsoft Excel" (Microsoft Office 2007). Визначали такі показники: середнє арифметичне (М), середнє квадратичне відхилення (б) і помилку середнього арифрметичного $(\mathrm{m})$. Статистичну значущість різниці між середніми арифметичними та відносними величинами за нормального розподілу оцінювали за критерієм Стьюдента-Фішера (t). При порівнянні однотипних груп проводили кореляційний аналіз з урахуванням коефріцієнта кореляції (r) за методом квадратів Пірсона.

РЕЗУЛЬТАТИ ДОСЛІДЖЕНЬ ТА ЇХ ОБГОВОРЕННЯ При гістологічному дослідженні у перші дві години після зняття турнікета (перша та друга групи дослідження) виявляли дезорганізацію структурних компонентів м'язових клітин, зменшення посмугованості, розволокненість, розриви та фррагментацію м'язових волокон (рис. 1, 2). Також мало місце порушення їх звивистості та нелінійне розміщення ядер. Структурні порушення наростали до кінця першої доби (третя група), ставали більш інтенсивними та поширеними. Спостерігались окремі некротичні ділянки та розташування ядер у міжклітинному просторі. Навколо таких ділянок виявлялась лімфоцитарна інфрільтрація. На 7-му добу (четверта група) простежувались подібні зміни, проте вони були локальними і менш вираженими. Відмічався набряк перимізію та ендомізію у

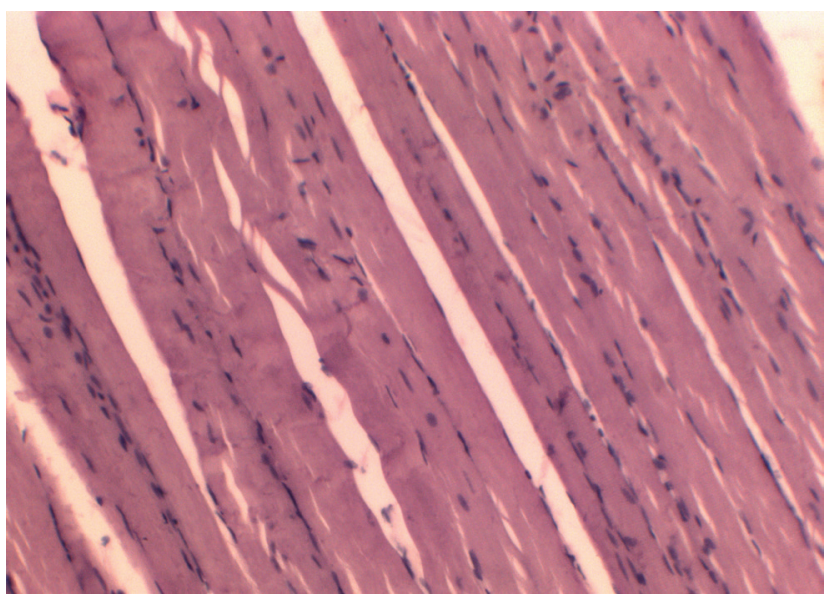

Рис. 1. Повздовжній переріз чотириголового м'яза щура. Посмугованість м'язових волокон, лінійне розташування ядер, контрольна група. Забарвлення гематоксиліном та еозином. ×100.

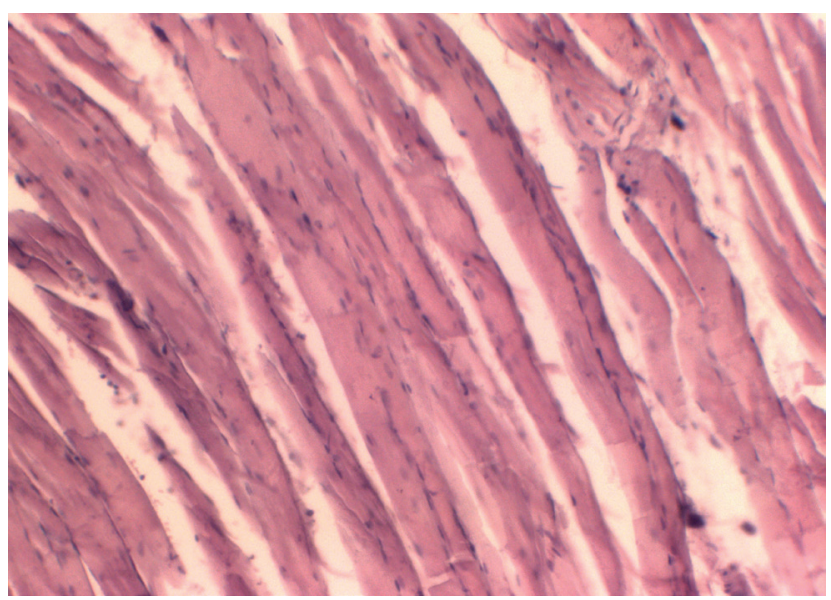

Рис. 2. Повздовжній переріз чотириголового м'яза щура. Фрагментація, втрата посмугованості м'язових волокон, порушення лінійного розташування ядер, наявність окремих ядер у міжклітинному просторі. Набряк інтерстиціального простору, друга година після зняття турнікета. Забарвлення гематоксиліном та еозином. $\times 100$.

поєднанні з проліферацією сполучнотканинних елементів. На 14-ту добу (п'ята група) м'язова тканина значною мірою відновлювала свою структуру - м'язові волокна мали однорідну структуру, ядра орієнтувались своїми довгими осями паралельно сарколемі. Виявлялись лише осередки розростанням волокнистої сполучної тканини та клітинної інфрільтрації.

Пересічна площа поперечного перерізу м'язових волокон у першу годину (перша група) після зняття турнікета $\left((1312,3 \pm 52,4)\right.$ мкм² $\left.^{2}\right)$ перевищувала аналогічний показник контрольної групи - $(1282,9 \pm 34,6)$ мкм $^{2}$ на 0,99 $\%(p>0,05)$. Через 2 год після зняття турнікета (друга група) пересічна площа поперечного перерізу м'язових волокон $(1364,7 \pm 22,7)$ мкм² $^{2}$ перевищувала на 2,21\% відповідний показник першої групи (p>0,05) та на 3,20 \% аналогічний показник групи контролю $(p<0,05)$. Найбільш вираженим набряк м'язової тканини був на першу добу (третя група). Пересічна площа поперечного перерізу м'язових волокон $(1369,2 \pm 26,6)$ мкм $^{2}$ у зазначеній групі перевищувала відповідний показник контрольної групи на 3,37 \% $(p<0,05)$, відповідний показник першої групи - 
на 2,36 \% $(p>0,05)$ та аналогічний показник другої групи - на 0,14\% (p>0,05).

На 7-му добу (четверта група) спостерігалась тенденція до зменшення пересічної площі поперечного перерізу м'язових волокон - $(1359,2 \pm 28,2)$ мкм² $^{2}$ Цей показник був на 0,36 \% нижчим, порівняно з відповідним показником третьої групи та на 0,22 \% - 3 аналогічним показником другої групи, проте виявлявся на 1,99 \% більшим порівняно з відповідним показником першої та на 2,98 \% групи контролю ( $>>0,05)$. На 14-ту добу (п'ята група) після зняття турнікета показник пересічної площі поперечного перерізу м'язових волокон $(1309,8 \pm 28,0)$ мкм2 не суттєво ( $>>0,05)$ різнився від аналогічних показників групи контролю і четвертої групи та був суттєво $(p<0,05)$ меншим від відповідного показника третьої групи.

Виявлявся і набряк ядер м'язових волокон, що був менш вираженим. Найвищий пересічний показник площі ядер спостерігали на першу добу спостереження (третя група). Пересічна площа ядер зазначеної групи $(64,03 \pm 0,08)$ мкм² незначно перевищувала відповідний показник першої - $(63,98 \pm 0,08)$ мкм² $^{2}$ р >0,05 та другої груп - $(63,99 \pm 0,12)$ мкм² $^{2}, p>0,05$. При цьому пересічна площа ядер м'язових волокон у першій групі також несуттєво $(p>0,05)$ різнилася від аналогічного показника контрольної групи - $(63,95 \pm 0,07)$ мкм². У другій групі пересічна площа ядер м'язових волокон перевищувала аналогічний показник контрольної групи та відповідний показник першої групи, проте статистично достовірної відмінності не виявлялось ( $>>0,05)$.

У четвертій групі дослідження було зменшення пересічної площі ядер м'язових волокон. Цей показник $(64,01 \pm 0,08)$ мкм² $^{2}$ був нижчим, порівняно 3 аналогічним показником третьої групи, та виявлявся вищим порівняно з аналогічним показником першої групи, другої групи та групи контролю $(p>0,05)$. На 14-ту добу після зняття турнікета (п'ята група) пересічна площа ядер м'язових волокон $(63,78 \pm 0,09)$ мкм² $^{2}$ мала тенденцію до зниження, порівняно з третьою групою, проте статистично значущої відмінності не виявлено ( $>>0,05)$.

Кореляційний аналіз виявив прямий кореляційний зв'язок $(+0,7)$ між показниками пересічних площ $\left(\mathrm{s}_{\mathrm{s}}\right)$ м'язових волокон та пересічних площ їх ядер $\left(\mathrm{s}_{\mathrm{n}}\right)$.

В усіх досліджуваних групах проведено також порівняльний аналіз рівня ЗБ, ТГ, креатиніну, холестерину, загального білірубіну, показника активності АлАТ, АсАТ та ЛФ (табл. 1).

Вміст ЗБ у сироватці крові щурів досягнув найнижчого значення $((58,90 \pm 2,10)$ г/л) на першу добу (третя група), що на 14,35 \% менше від відповідного показника контрольної групи ( $>>0,05)$, на 3,68 \% - відповідного показника першої групи (p>0,05) та на 6,69 \% - аналогічного показника другої групи ( $>0,05)$.

У групі тварин моделі пізнього постішемічного періоду вміст ЗБ зріс на 7-му добу (четверта група). Зазначений показник $(61,77 \pm 2,15)$ г/л виявлявся вищим, порівняно 3 аналогічним показником третьої групи, на 4,87 \%, хоча все ще залишався нижчим, порівняно з аналогічним показником групи контролю, на 10,18 \% (р>0,05). На 14-ту добу вміст ЗБ у сироватці крові $((60,75 \pm 2,76)$ г/л) суттєво не різнився із відповідним показником першої та третьої груп (p>0,05) і був на 11,66 \% нижчим, порівняно з аналогічним показником групи контролю, проте ця відмінність була статистично незначущою ( $>>0,05)$.

Вміст ТГ поступово знижувався у тварин перших трьох груп, досягши мінімального показника $((0,52 \pm 0,04)$ ммоль/л) у третій групі, що на 17,46 \% нижче порівняно 3 відповідним показником групи контролю (р>0,05). На 7-му добу (четверта група) показник рівня ТГ у сироватці крові щурів досягнув максимального рівня $((1,00 \pm 0,21)$ ммоль/л) та був на 92,31 \% вищим, порівняно з відповідним показником третьої групи, та на 58,73 \% більшим - із відповідним показником контрольної групи ( $>>0,05)$. Вміст ТГ на $14-y$ добу $((0,72 \pm 0,08)$ ммоль/л) зменшився відносно попередньої групи на 28,0 \% і був вищим порівняно з аналогічним показником контрольної групи лише на 14,29 \% (p>0,05).

Пересічний показник вмісту креатиніну в сироватці крові щурів першої групи $((49,45 \pm 1,60)$ мкмоль/л) виявлявся меншим, порівняно 3 групою контролю, на 7,71 \% (р>0,05), а в другій групі $((45,53 \pm 1,48)$ мкмоль/л) - на 15,02 $\%(p<0,05)$. У третій групі спостерігали максимальний рівень креатиніну - ((55,78 $\pm 3,71)$ мкмоль/л), що на 22,51 $\%$ перевищував значення попередньої групи ( $>>0,05)$. У четвертій та п'ятій групах тварин - $((49,45 \pm 1,54)$ і $(49,92 \pm 0,89)$ мкмоль/л відповідно) показники креатиніну були на 7,71 та 6,83 \% нижчими від показників контрольної групи, проте ця відмінність не була статистично значущою $(p>0,05)$.

Таблиця 1. Зміни пересічної площі $\left(s_{s}\right)$ м'язових волокон, пересічної площі їх ядер (s $)$ та біохімічних показників у

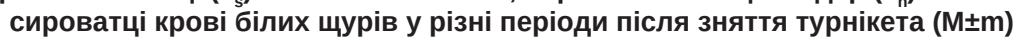

\begin{tabular}{|c|c|c|c|c|c|c|}
\hline Показник & Контроль & $\begin{array}{c}\text { Перша група } \\
\text { (1 год) }\end{array}$ & $\begin{array}{c}\text { Друга група } \\
\text { (2 год) }\end{array}$ & $\begin{array}{c}\text { Третя група } \\
\text { (1 доба) }\end{array}$ & $\begin{array}{c}\text { Четверта група } \\
\text { (7 доба) }\end{array}$ & $\begin{array}{c}\text { П'ята група } \\
\text { (14 доба) }\end{array}$ \\
\hline $\mathrm{S}_{\mathrm{s}} \mathrm{MKM}^{2}$ & $1282,9 \pm 34,6$ & $1312,3 \pm 52,4$ & $1364,7 \pm 22,7^{*}$ & $1369,2 \pm 26,6^{*}$ & $1359,2 \pm 28,2$ & $1309,8 \pm 28,0$ \\
\hline $\mathrm{S}_{\mathrm{n}} \mathrm{MKM}^{2}$ & $63,96 \pm 0,08$ & $63,98 \pm 0,08$ & $63,99 \pm 0,12$ & $64,03 \pm 0,08$ & $64,01 \pm 0,08$ & $63,78 \pm 0,10$ \\
\hline Загальний білок (г/л) & $68,77 \pm 5,82$ & $61,15 \pm 2,83$ & $63,12 \pm 1,40$ & $58,90 \pm 2,10$ & $61,77 \pm 2,15$ & $60,75 \pm 2,76$ \\
\hline Тригліцериди (ммоль/л) & $0,63 \pm 0,08$ & $0,61 \pm 0,05$ & $0,53 \pm 0,03$ & $0,52 \pm 0,04$ & $1,00 \pm 0,21$ & $0,72 \pm 0,08$ \\
\hline Креатинін (мкмоль/л) & $53,58 \pm 1,51$ & $49,45 \pm 1,60$ & $45,53 \pm 1,48^{*}$ & $55,78 \pm 3,71$ & $49,45 \pm 1,54$ & $49,92 \pm 0,89$ \\
\hline Холестерин (ммоль/л) & $1,56 \pm 0,10$ & $1,37 \pm 0,10$ & $1,47 \pm 0,18$ & $1,77 \pm 0,11$ & $1,39 \pm 0,13$ & $1,38 \pm 0,07$ \\
\hline Загальний білірубін (мкмоль/л) & $3,02 \pm 0,26$ & $5,03 \pm 0,64^{*}$ & $6,20 \pm 0,31^{\star \star \star}$ & $3,86 \pm 0,31^{* * \star *}$ & $3,69 \pm 0,42$ & $4,19 \pm 0,40$ \\
\hline АлАТ (од./л) & $61,40 \pm 4,05$ & $65,1 \pm 7,22$ & $82,08 \pm 7,93^{*}$ & $116,35 \pm 8,33^{* \star *}$ & $57,75 \pm 2,84^{\star \star \star \star}$ & $60,92 \pm 3,14$ \\
\hline АсАТ (од./л) & $354,1 \pm 57,7$ & $563,83 \pm 58,30$ & $632,9 \pm 73,00^{* * *}$ & $598,78 \pm 55,10$ & $311,60 \pm 18,48^{* *}$ & $367,5 \pm 63,46$ \\
\hline ЛФ (од./л) & $411,8 \pm 74,9$ & $425,1 \pm 133,3$ & $405,3 \pm 54,5$ & $528,05 \pm 39,1$ & $600,4 \pm 62,5$ & $488,5 \pm 18,1$ \\
\hline
\end{tabular}

Примітки: 1) * - p<0,05 порівняно 3 групою контролю;

2) ** $-p<0,05$ порівняно з попередньою групою;

3) *** - p<0,005 порівняно 3 групою контролю;

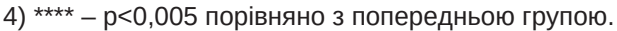


Показник рівня холестерину $((1,37 \pm 0,1)$ ммоль/л) в сироватці крові щурів у першій групі зменшився на 12,18 \% порівняно групою контролю (р>0,05). У третій групі зазначений показник $((1,77 \pm 0,11)$ ммоль/л) був вищим від аналогічного показника другої групи $((1,47 \pm 0,18)$ ммоль/л)) на $29,2 \%(p>0,05)$ та на 13,46 \% - порівняно з показником контрольної групи (p>0,05). У четвертій $((1,39 \pm 0,13)$ ммоль/л) та п'ятій $((1,38 \pm 0,07)$ ммоль/л) групах рівень холестерину наближався до рівня відповідного показника першої групи, що, відповідно на 10,9 та 11,54 \% нижче аналогічного показника групи контролю $(p>0,05)$.

У першій та другій групах тварин відмічено статистично значуще підвищення показника загального білірубіну. Так, зазначений показник першої групи $((5,03 \pm 0,64)$ мкмоль/л) був вищим на 66,56 \% порівняно з показником контрольної групи $(p<0,05)$. У другій групі показник загального білірубіну $((6,20 \pm 0,31)$ мкмоль/л) виявлявся на 105,3 \% вищим, порівняно 3 аналогічним показником групи контролю (р<0,005), та на 23,26 \% - із відповідним показником першої (p>0,05). У третій концентрація загального білірубіну $((3,86 \pm 0,31)$ мкмоль/л) зменшилась на 37,74 \% відносно показника попередньої групи $(p<0,005)$ і була вищою на 27,81 \% порівняно з показником контрольної групи (p>0,05). У четвертій групі рівень загального білірубіну $((3,69 \pm 0,45)$ мкмоль/л) зменшився відносно попередньої групи на 4,4 \% (p>0,05). У п'ятій групі зазначений показник $((4,19 \pm 0,40)$ мкмоль/л) зріс на $13,55 \%$, порівняно з попередньою групою тварин ( $p>0,05)$, та на 38,74 \% порівняно 3 контрольною групою $(p>0,05)$.

Виявлялись високі показники активності АлАТ у першій, другій та третій групах тварин. Так, у другій групі значення даного показника $((82,08 \pm 7,93)$ од./л) перевищувало відповідне значення групи контролю на 33,68 \% $(p<0,05)$. Максимального значення показник активності АлАТ $((116,35 \pm 8,33)$ од./л) досягнув у третій групі тварин, що вище аналогічних показників другої групи на 78,73 \% $(p<0,05)$ та групи контролю - на 89,5 \% $(p<0,05)$. Зазначений показник у четвертій групі становив $((57,75 \pm 2,84)$ од./л, що нижче, порівняно з попередньою, на 50,37 \% ( $<<0,005)$. На 14-ту добу репердузії (п'ята група тварин) показник активності АлАТ $((60,92 \pm 3,14)$ од./л) не суттєво різнився порівняно з аналогічним показником контрольної групи (р>0,05).

У ранній реперфузійний період відмічалось зростання активності АсАТ у першій, другій та третій групах тварин. У тварин з двогодинною реперфузією показник досягнув максимального значення $((632,90 \pm 73,0)$ од./л), що на 78,73 \% вище за групу контролю $(p<0,005)$. У третій групі показник активності АсАТ $((598,78 \pm 55,1)$ од./л) залишався високим. У четвертій групі показник активності АсАТ $((311,60 \pm 18,48)$ од./л) досягнув мінімального значення і був на 47,96 \% нижчим, порівняно 3 аналогічним показником попередньої групи $(p<0,05)$, а в п'ятій групі $((367,50 \pm 63,46)$ од./л) - лише на 3,78 \% вищим порівняно з відповідним показником групи контролю (р>0,05).

Пересічний показник активності ЛФ у першій та другій групах істотно не відрізнявся від відповідного показника групи контролю $((411,8 \pm 74,9)$ од./л) (р>0,05). Суттєве підвищення активності ЛФ спостерігали на першу добу в третій групі $((527,95 \pm 39,05)$ од./л), що на 28,2 \% вище порівняно з аналогічним показником контрольної групи ( $>>0,05)$. Максимальна активність ЛФ була у четвертій групі щурів. Зазначений показник $((600,37 \pm 62,47)$ од./л) виявлявся на 12,72 \% вищим, порівняно з відповідним показником попередньої групи, та на 45,78 \% вищим, порівняно з аналогічним показником групи контролю, хоча ці відмінності не були статистично значущими ( $>>0,05)$. У п'ятій групі досліджуваних тварин зазначений показник $((488,47 \pm 18,09)$ од./л) зменшився на $18,64 \%$, порівняно 3 четвертою групою ( $>>0,05)$, залишаючись на $18,61 \%$ вищим порівняно з аналогічним показником групи контролю ( $>>0,05)$.

Кореляційний аналіз виявив прямий кореляційний зв'язок між показниками пересічної площі $\left(\mathrm{s}_{\mathrm{s}}\right)$ м'язових волокон та показниками креатиніну $(+0,1)$, холестерину $(+0,4)$, загального білірубіну $(+0,1)$, АлАТ $(+0,5)$, АлАТ $(+0,5)$ та ЛФ $(+0,1)$, а також зворотний кореляційний зв'язок між показниками пересічної площі $\left(\mathrm{s}_{\mathrm{s}}\right)$ м'язових волокон і рівнем тригліцеридів $(-0,1)$ досліджуваних груп. Аналогічна закономірність виявлялась і щодо пересічної площі їх ядер $\left(\mathrm{s}_{\mathrm{n}}\right)$. Спостерігався прямий кореляційний зв'язок між показниками пересічної площі ядер $\left(\mathrm{s}_{\mathrm{n}}\right)$ м'язових волокон та показниками креатиніну $(+0,3)$, холестерину $(+0,6)$, АлАТ $(+0,6)$, АлАТ $(+0,3)$ та ЛФ $(+0,3)$, а також зворотний кореляційний зв'язок між показниками пересічної площі $\left(\mathrm{s}_{\mathrm{s}}\right)$ м'язових волокон і рівнем тригліцеридів $(-0,1)$.

Висновки 1. При дослідженні скелетної мускулатури задніх кінцівок білих щурів після гострої ішемії, спричиненої накладанням турнікета, встановлено, що морфологічні зміни м'язових волокон проявлялося в основному набуханням, гомогенізацією саркоплазми, порушенням лінійного розміщення ядер в міоцитах та лейкоцитарною інфільтрацією ендо- і перимізію. В окремих випадках був міоліз із руйнуванням сарколеми та виходом ядер у міжклітинний простір.

2. Структурні порушення наростали до кінця першої доби та мали односпрямований і прогредієнтний характер, про що свідчили результати проведеного морфометричного аналізу. Найзначніший ішемічний набряк м'язової тканини мав місце на першу добу в третій групі

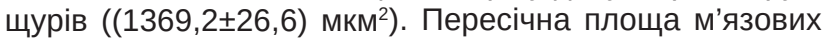
волокон у цій групі перевищувала на 3,37 \% відповідний показник $\left((1282,9 \pm 34,6)\right.$ мкм²$\left.^{2}\right)$ контрольної групи $(p<0,05)$. При цьому виявлялась сильна позитивна кореляція із показниками площі ядер $(+0,7)$, хоча морфологічні зміни ядер не були такими виразними. Пересічна площа ядер

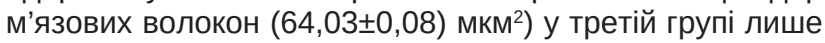
незначно перевищувала відповідний показник

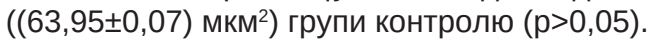

3. Порівняльний аналіз змін морфометричних та біохімічних показників виявив найбільш виражені порушення у другій та третій групах тварин моделі раннього періоду ішемічного ураження.

4. Зниження вмісту креатиніну в другій групі (реперфуззія 2 год) на 15,02 \% відносно групи контролю $(p<0,05)$ може свідчити про затримку виділення креатиніну в кров у зв'язку з порушенням кровопостачання значного масиву м'язової тканини. У результаті подальшого відновлення кровопостачання вміст креатиніну нормалізувався. Це підтверджує і виявлений прямий кореляційний зв'язок між показниками пересічної площі м'язових волокон $(+0,1)$ та їх ядер $(+0,3)$ і показниками креатиніну.

5. Несуттєве підвищення пересічного показника рівня холестерину в сироватці крові (на 13,26 \%), яке виявлялось на першу добу ішемічного ураження ( $>>0,05)$, вказує, на нашу думку, на незначний вплив ішемії-реперфузії на обмін холестерину в організмі. При цьому зміни холесте- 
ринового обміну розвиваються порівняно швидко, що підтверджує кореляція з рівнем набряку м'язових волокон $(+0,4)$ та їх ядер $(+0,6)$ при розвитку реперфузійно-ішемічного синдрому.

6. Статистично значуще підвищення вмісту загального білірубіну на $66,54 \%$ в першій групі $(p<0,05)$ та на 105,41 \% в другій групі (р<0,005) досліджуваних тварин відносно показників контрольної групи свідчить про розвиток гемолізу еритроцитів унаслідок ушкодження їх клітинних мембран продуктами пероксидного окиснення ліпідів. При цьому повернення зазначеного показника до норми слабко корелювало $(+0,1)$ із спаданням набряку м'язових волокон, що може вказувати на пізній розвиток компенсаторних механізмів у цьому сегменті.

7. Статистично значуще підвищення рівня трансаміназ у сироватці крові щурів свідчить про ішемічне ураження значного масиву м'язової тканини, а також вказує на системне ураження внутрішніх органів продуктами метаболізму та пероксидного окиснення ліпідів. При цьому зростання АлАТ досягло максимуму в третій групі тварин на першу добу (на 89,5 \% вище відповідного показника контрольної групи, p<0,005), а рівень АсАТ був найвищий у другій групі щурів (на 78,73 \% вище аналогічного показника контрольної групи, р<0,005), хоча продовжував залишатись високим і в третій групі (на 69,10 \% вище відповідного показника групи контролю, р>0,05). На важливе патогенетичне значення змін рівня трансаміназ при розвитку реперсузійно-ішемічного синдрому вказує і середній прямий кореляційний зв'язок між показниками

\section{СПИСОК ЛІТЕРАТУРИ}

1. Покровский А. В. Национальные рекомендации по ведению пациентов с заболеваниями артерий нижних конечностей I А. В. Покровский, Л. А. Бокерия. - М. , 2013. - 67 с.

2. Губка В. О. Результати лікування хворих із гострою артеріальною ішемією кінцівок / В. О. Губка, І. А. Коноваленко, О. В. Суздаленко // Патологія. - 2015. - № 2 (34). - С. 55-58.

3. Реперфузионный синдром у больных с хронической ишемией нижних конечностей / А. В. Гавриленко, И. И. Дементьева, Д. А. Майтесян [и др.] // Ангиология и сосуд. хирургия. -2002. - № 3. - С. 90-95.

4. Гавриленко А. В. Состояние микроциркуляции при реперфрузионном синдроме после реконструктивных операций на сосудах нижних конечностей / А. В. Гавриленко, Е. Д. Шабалтас // Хирургия. - 2003. - № 2 - С. 62.

5. Геник С. М. Реперфузійний синдром після реваскуляризації ішемії нижніх кінцівок / С. М. Геник, А. В. Симчич // Серце і судини. - 2016. - № 3. - С. 104-108.

6. Келина Н. Ю. Биохимические проявления эндотоксикоза : метод. аспекты изучения и оценки, прогностическая значимость (аналитический обзор) / Н. Ю. Келина, Н. В. Безручко, Г. К. Рубцов // Вестник Тюменского государственного университета. 2012. - № 6. - С. 143-147.

7. Фармакологическая профилактика реперфузионного синдрома у пострадавших с тяжелыми сочетанными травмами сопровождающимися шоком / Ю. С. Полушин, Б. Н. Шах, В. М. Теплов [и др.] // Вестник хирургии имени И.И. Грекова 2013. - Т. 172, № 5 - C. 41-45. пересічної площі (ss) м'язових волокон та показниками АлАТ $(+0,5)$ і АсAТ $(+0,5)$.

8. Зростання пересічного показника активності ЛФ у третій групі (на 28,2 \%), який досягнув максимального значення $((600,37 \pm 62,47)$ од./л) в четвертій групі експериментальних тварин, не було статистично значущим $(p>0,05)$. При цьому мала місце позитивна слабка кореляція із набряком м'язових волокон $(+0,1)$, що можна пояснити незначним ураження печінки із поступовим розвитком змін унаслідок прогресування реперфузійноішемічного синдрому.

9. У тварин моделі пізнього постішемічного періоду (четверта і п'ята групи) спостерігалось повернення більшості біохімічних показників сироватки крові до значень, близьких до показників контрольної групи. Простежувався лише підвищений рівень тригліцеридів відносно групи контролю, проте статистично значущої достовірності при цьому не виявлено ( $>0,05)$. Мала місце і слабка негативна кореляція $(-0,1)$ зазначеного показника із морфологічними змінами м'язових волокон.

Перспективи подальших досліджень Результати порівняльного аналізу ремоделювання м'язових волокон та змін біохімічних показників сироватки крові підтверджують розвиток у піддослідних тварин ішемічно-реперфрузійного синдрому. Виявлені при цьому закономірності та тенденції можуть бути використані для подальших досліджень та розробки нових напрямків корекції структурно-срункціональних порушень м'яких тканин нижніх кінцівок при різних видах компресійної травми.

8. Safe tourniquet use: a review of the evidence /P. G. Fitzgibbons, C. Digiovanni, S. Hares [et al.] // J. Am. Acad. Orthop. Surg. - 2012. - Vol. 20. - P. 310-319.

9. Drew B. Application of current hemorrhage control techniques for backcountry care: Part one, tourniquets and hemorrhage control adjuncts / B. Drew, B. Bennett, L. Littlejohn // Wilderness and Environmental Medicine. - 2015. - No. 26. - P. 236-245.

10. Физиологические, биохимические и биометрические показатели нормы экспериментальных животных : справочник I под ред. В. Г. Макарова, М. Н. Макаровой. - СПб. : Изд-во “Лема", 2013. -116 c.

11. Metabolic alterations of skeletal muscle tissue after prolonged acute ischemia and reperfusion / A. Kabaroudis, T. Gerassimidis, D. Karamanos [et al.] // Journal of Investigative Surgery. - 2003. Vol. 16 (4). - P. 219-228.

12. Османова А. А. Динамика микроциркуляторного русла при компрессионной травме мягких тканей конечностей и коррекции инфузией перфторана : дисс. канд. мед. наук : спец. 14.03.01 "Анатомия человека" / А. А. Османова. - Махачкала, 2010. - 162 c.

13. Молекулярные механизмы развития и адресная терапия синдрома ишемии-реперфузии / О. А. Гребенчиков, В. В. Дихванцев, Е. Ю. Плотников [и др.] // Актуальные вопросы анестезиологии и реаниматологии. - 2014. - № 3. - С. 59-67.

14. Blaisdell F. W. The pathophysiology of skeletal musculeishemia and the reperfusion syndrome: a rewiew / F. W. Blaisdell // Cardiovasc. Surg. - 2002. - Vol. 10. - P. 620-630.

15. Меркулов Г. А. Курс патологогистологической техники / Г. А. Меркулов. - Л. : Медицина, 1969. - 423 с.

Отримано 20.06.18 


\section{THE COMPARATIVE ANALYSIS OF STRUCTURAL CHANGES IN MUSCLES OF THE HIND LIMBS AND BIOCHEMICAL CHANGES IN BLOOD SERUM OF THE RATS WITH ACUTE ISCHEMIA}

Summary. Acute limb ischemia occurs as a result of sudden decrease in its perfusion, which usually occurs during the obturation of the lumen of large arteries due to acute thrombosis or embolism either impaired of vascular patency caused by trauma or compression (including the application of hemostatic tourniquets). In case of restoration of blood supply to the previously ischemic tissues arises an ischemic-reperfusion syndrome (IRS), pathophysiological links of which are the important mechanisms of the tissue changes. The aim of the study - to make the comparative analysis of structural changes in muscle fibers and biochemical changes in the blood serum in case of acute ischemia caused by the application of an arterial tourniquet on the hind limbs of rats.

Materials and Methods. The histological and morphometric study of the tissues of the four-head muscles of the hind limbs of 60 rats under condition of experimental acute ischemia were performed. There were 11 intact animals in the control group. Acute ischemia was caused by the application of SWAT (Stretch-Wrap-And-Tuck) rubber bands on the hind limbs of the animals. The histological investigation was carried out according to standard methods. The surface layers of the four-headed muscle of the hind limb of the rats were studied in the middle third of the thigh below the overlapping area of the tourniquet. By the morphometric examination following parameters were determined: the mean diameter of muscle fibers, the mean cross-sectional area of muscle fibers, the average diameter and the nuclei area of muscle fibers. The biochemical changes, namely the indices of total bilirubin, triglycerides (TG), cholesterol, creatinine, total protein (TP), alkaline phosphatase (AF) and the level of transaminases (ALAT, ASAT) were determined in blood serum of each group. Quantitative indicators were processed statistically.

Results and Discussion. The comprehensive analysis of the obtained data revealed that the pathological changes in the muscle tissue were aroused in the early period of the postischemic lesions and increased to the end of the 1st day. Histological examination revealed the following changes in the muscle tissue: the disorganization of structural components of the muscle cells, the reduction of the striation, edema, friability, fluffiness and rupture of the muscle fibers. The most significant edema of the muscle tissue occurred on the 1st day in the third group of rats. The average cross-sectional area of the fibers $\left.(1369.15 \pm 26.57) \mu m^{2}\right)$ is $6.72 \%$ higher than the corresponding index of the control group $(P<0.05)$ and the average diameter $((41.73 \pm 0.39) \mu \mathrm{m})$ was exceeded by $3.37 \%$ the index of the control group $(P<0.05)$. The average area of the nuclei of the muscle fibers $\left((64.03 \pm 0.08) \mu m^{2}\right)$ in the third group was only slightly higher than the corresponding value $((63.95 \pm 0.07) \mu \mathrm{m})$ of the control group $(P<0.05)$. The laboratory researches of biochemical parameters of the blood serum showed increasing activity of transaminases, AF and total bilirubin, decreasing creatinine and total protein (TB) in the early reperfusion period. In particular, in comparison with the corresponding index of the control group, the level of ALAT reached its the highest index in the first day, $(89.5 \%$ higher $)(P<0.05)$ and the ASAT index was the highest in the animals with 2-hour reperfusion ( $78.73 \%$ higher) $(P<0.005)$, the index of $A F$ and total bilirubin reached its maximum on the 7 th day (45.78\% and $105.3 \%$ higher respectively than the index of the control group) $(P<0.005)$. Correlation analysis revealed a direct correlation between the parameters of the average area $\left(s_{s}\right)$ of muscle fibers and the average area of their nuclei $\left(s_{)}\right)(+0.7)$, the indicators of creatinine (+0.1), cholesterol $(+0.4)$, total bilirubin $(+0,1)$, ALAT $(+0,5)$, AsAT $(+0,5)$ and AF $(+0,1)$, in addition the inverse correlation between the indices of the average area $\left(\mathrm{s}_{\mathrm{s}}\right)$ of muscle fibers and the level of triglyceride $(-0.1)$ of the studied groups. The similar pattern is manifested in relation to the average area of their nuclei $\left(\mathrm{s}_{n}\right)$ and mentioned biochemical indicators.

Conclusions. The results of remodeling of the muscle fibers confirm the development of ischemic-reperfusion syndrome in experimental animals. During the investigation of the skeletal muscles of the hind limbs of the white rats after acute ischemia caused by the application of the tourniquet was found that the remodeling of the muscle fibers was mainly manifested by edema, homogenization of sarcoplasm, violation of linear arrangement of nuclei in the myocytes and leukocyte infiltration of endo- and perimizia, myolysis with the destruction of the sarcolemma and release of nuclei into the intercellular space. The reactive lesions were developed in the microvessels of all segments and maximally expressed to the end of the 1st day. Changes in biochemical indices were most pronounced in the animals of the early period model of postischemic lesions ( $2^{\text {nd }}$ hour and $1^{\text {st }}$ day). In this period, in the blood serum of the experimental rats, a statistically significant increasing in the content of total bilirubin level, rising the transaminases level, increasing average AF activity, and decreasing in the content of TP and creatinine were observed. Changes in biochemical indices of blood homeostasis were developed synchronously with morphological, that proofs a direct correlation between the change in the average area of muscle fibers (and their nuclei) and changes in the blood serum content of the total bilirubin, cholesterol, creatinine, total protein (TB), alkaline phosphatase (AF) and transaminase levels (ALAT, ASAT).

Key words: acute ischemia; muscle tissue; muscle fiber; biochemical indices; reperfusion-ischemic syndrome.

(А. Т. Телевяк, Т. О. Вересюк, П. Р. Сельский

ГВУз “Тернопольский государственный медицинский университет имени И. Я. Горбачевского”

\section{СРАВНИТЕЛЬНЫЙ АНАЛИЗ СТРУКТУРНЫХ НАРУШЕНИЙ МЫШЦ ЗАДНИХ КОНЕЧНОСТЕЙ И ИЗМЕНЕНИЙ БИОХИМИЧЕСКИХ ПОКАЗАТЕЛЕЙ СЫВОРОТКИ КРОВИ КРЫС ПРИ ОСТРОЙ ИШЕМИИ}

Резюме. Острая ишемия конечности возникает в результате внезапного снижения ее перфузии, что обычно образуется при обтурации просвета крупных артерий вследствие их острого тромбоза или эмболии, а также нарушения проходимости сосудов, вызванного их травмами или сжатием (включая применение кровеостанавливающих турникетов). В случае возобновленния кровеснабжения в ранее ишемизированных тканях возникает ишемически-реперфузионный синдром, патофизиологические звенья которого являются важными механизмами альтерации тканей.

Цель исследования - провести сравнительный анализ структурных изменений мышечных волокон и изменений биохимических показателей сыворотки крови при острой ишемии, вызванной наложением артериального турникета на задние конечности крыс.

Материалы и методы. Было проведено гистологическое и моророметрическое исследования тканей четырехглавых мышц задних конечностей 60 крыс в условиях экспериментальной острой ишемии. В контрольной группе было 11 интактных животных. Острую ишемию вызывали путем наложения резиновых жгутов SWAT (Stretch-Wrap-And-Tuck) на задние конечности животных. 
ISSN 1681-276Х. ВІСНИК НАУКОВИХ ДОСЛІДЖЕНЬ. 2018. № 3

Гистологическое исследование проводилось по общепринятым методикам. Исследовались поверхностные слои четырехглавой мышцы задней конечности крыс в средней трети бедра ниже участка наложения жгута. При морфометрическом исследовании определялись следующие показатели: средний диаметр мышечных волокон, средняя площадь поперечного сечения мышечных волокон, средние диаметр и площадь ядер мышечных волокон. Биохимические изменения, в частности показатели содержания общего билирубина, триглицеридов, холестерина, креатинина, общего белка, щелочной фоссратазы и уровень трансаминаз (АлАТ, АсАТ) определяли в сыворотке крови в каждой исследуемой группе. Количественные показатели обрабатывались статистически.

Результаты исследований и их обсуждение. Анализ полученных данных показал, что патологические изменения мышечной ткани возникали уже в ранний период постишемического поражения и нарастали к концу первых суток. При гистологическом исследовании наблюдались следующие изменения тканей мышц: дезорганизация структурных компонентов мышечных клеток, уменьшение исчерченности, отек, разрыхленность, розволокненность и разрывы мышечных волокон. Наиболее значительный отек мышечных волокон имел место в первые сутки в третьей группе крыс. Средняя площадь поперечного

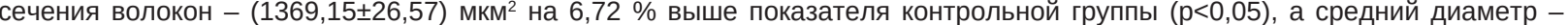
$(41,73 \pm 0,39)$ мкм на $3,37 \%$ превышал контрольный показатель $(p<0,05)$. Средняя площадь ядер мышечных волокон $(64,03 \pm 0,08)$ мкм² $^{2}$ в третьей группе лишь незначительно превышала соответствующий показатель - $(63,95 \pm 0,07)$ мкм² $^{2}$ группы контроля (p>0,05). Лабораторные исследования биохимических показателей сыворотки крови показали возрастание содержания щелочной фоссратазы, общего билирубина и активности трансаминаз, снижение уровня креатинина и общего белка в раннем реперфузионном периоде. В частности, в сравнении с соответствующим показателем контрольной группы, уровень АлАТ достиг своего наивысшего значения в первые сутки (выше на 89,5 \%) (p<0,05), а показатель АсАТ максимальным был у животных с двухчасовой реперфузией (выше на 78,73 \%) (p<0,005), уровень щелочной фросфратазы и общего биллирубина достигли своего максимума на 7-е сутки (выше на 45,78 та 105,3 \% соответственно) (p<0,005). Корреляционный анализ показал прямую корреляционную связь между показателем средней площади мышечных волокон (s $)$ и средней площадью их ядер $\left(s_{n}\right)(+0,7)$, содержанием креатинина $(+0,1)$, холестерина $(+0,4)$, общего билирубина $(+0,1)$, АлАТ $(+0,5)$, AcAT $(+0,5)$ и щелочной фоссратазы $(+0,1)$, а также обратную корреляционную связь между показателем средней площади $\left(\mathrm{s}_{\mathrm{s}}\right)$ мышечных волокон и уровнем триглицеридов $(-0,1)$ исследуемых групп. Аналогичная закономерность выявлялась между средней площадью их ядер $\left(\mathrm{s}_{\mathrm{n}}\right)$ и упомянутыми биохимическими показателями.

Выводы. Результаты ремоделирования мышечных волокон подтверждают развитие у подопытных животных ишемическиреперфузионного синдрома. При исследовании скелетных мышц задних конечностей белых крыс после острой ишемии, вызванной наложением турникета, установлено, что ремоделирование мышечных волокон проявлялось в основном отеком, гомогенизацией саркоплазмы, нарушением линейного расположения ядер в миоцитах и лейкоцитарной инсрильтрацией эндои перимизия, миолизом с разрушением сарколеммы и выходом ядер в межклеточное пространство. Реактивные нарушения развивались также в микрососудах всех сегментов и были максимально выраженными к концу первых суток.

Ключевые слова: острая ишемия; мышечная ткань; мышечное волокно; биохимические показатели; ишемическиреперфузионный синдром. 